\title{
ENTRE LO REGIONAL Y LO INDUSTRIAL: LA ANOMALÍA DE FILM ANDES (1944-1956)
}

\author{
Between regional and industrial:Film Andes' anomaly (1944-1956)
}

\author{
Alejandro Kelly Hopfenblatt* \\ https://orcid.org/0000-0001-6951-5289
}

\begin{abstract}
Resumen
Las historias del cine argentino suelen entender el período clásico como un momento de producción industrial centrada exclusivamente en Buenos Aires y toda instancia alternativa es mirada usualmente como una curiosidad menor, sin adentrarse en profundidad en sus particularidades. En este sentido, la productora mendocina Film Andes, que produjo dieciséis películas entre 1944 y 1956 que abarcaron desde adaptaciones de clásicos de la literatura universal a films localistas de contenido social, supone un caso de marcado interés ya que pone en tensión los parámetros que han guiado el estudio de las cinematografías regionales. Se propone en este artículo analizar el carácter anómalo de la compañía dentro de la historia del cine argentino a partir de un estudio de las prácticas comerciales y empresariales que llevó adelante, de los modelos narrativos y de representación de sus películas, así como de los puntos de contacto que se pueden establecer entre su desarrollo y los de otras experiencias contemporáneas.
\end{abstract}

$<$ Film Andes $><$ Cine argentino clásico $><$ Cine regional $><$ Industria cinematográfica $>$

\begin{abstract}
Argentine film histories tend to present the classical period as a moment where film production was centered exclusively in Buenos Aires, and any alternative experience is viewed as a minor curiosity which requires not much interest. Taking this into consideration, Film Andes, a production company based in Mendoza province which produced sixteen movies between 1944 and 1956 that ranged from adaptations of classical literature to local stories with social themes, entails a peculiar case that puts a strain on the frameworks used to study regional cinemas. This article analyzes the anomalies this company introduces into Argentine film history by studying its commercial and business strategies, its narrative and representational models, and its similarities to other contemporaneous experiences.
\end{abstract}

$<$ Film Andes $><$ Argentine Classical Cinema $><$ Regional Cinema $><$ Film Industry $>$

Recibido: 28/09/2020//Aceptado: 27/11/2020

* Centro de Investigación y Nuevos Estudios sobre Cine (ClyNE), Instituto del Arte Argentino y Latinoamericano, Facultad de Filosofía y Letras, Universidad de Buenos Aires (UBA), Argentina, alejandro.kelly.h@gmail.com 


\section{Introducción}

En el año 2000 se publicaron los dos libros dedicados al cine clásico de la Historia del Cine Argentino que dirigió Claudio España para el Fondo Nacional de las Artes. Bajo el denominador de Industria y clasicismo, ambos volúmenes combinaban una historia de la industria fílmica nacional con una perspectiva centrada en los géneros cinematográficos. Para ello, mientras que el segundo tomo presentaba capítulos sobre la comedia, el policial o el melodrama, el primero se componía de artículos centrados en las diversas compañías productoras que existieron en esos años. De este modo, se contaban escritos dedicados tanto a grandes empresas — como Argentina Sono Film o Lumiton - hasta emprendimientos de menor dimensión e impacto, como Mapol o Cinematográfica Cinco.

Un último capítulo en este recorrido industrial, escrito por Gregorio Anchou (2000), proponía una revisión de lo que se denominaba la "producción independiente". Allí, se presentaba un conjunto diverso de empresas que tensionaban el propio concepto, ya que incluían desde las producciones autogestionadas de Julio Irigoyen a proyectos de aspiraciones cosmopolitas como la Sociedad Industrial Fotográfica Argentina Ltda. (SIFAL) de Luis Saslavsky. El autor reconocía esta heterogeneidad, que residía principalmente en una decisión metodológica al momento de abordar de modo exhaustivo el campo productor nacional. Dentro de este variado panorama se encontraba Film Andes, una compañía mendocina que, a lo largo de más de una década, tuvo un desarrollo que pone en cuestión su inclusión dentro de un espacio alternativo o independiente.

Fundada en 1944 y disuelta hacia 1956, la empresa fue el producto de un emprendimiento llevado adelante por empresarios del sector vitivinícola mendocino para desarrollar un Hollywood local. A partir de la conjunción de condiciones geográficas y climáticas, que permitían homologar el territorio cuyano a California, y con una mirada centrada en la industria cinematográfica como un símbolo de modernidad y distinción, la empresa fue pensada como un proyecto con estructuras y mecanismos asimilables a los que existían en Buenos Aires. Siguiendo esta línea se construyeron estudios propios de filmación, se desarrollaron estrategias de distribución y exhibición comercial y se filmaron temas y relatos locales e internacionales con ambientaciones en diversos tiempos y espacios. A lo largo de quince películas se contó con la participación de nombres destacados del cine nacional como Alberto de Zavalía, Carlos Borcosque, Carlos Hugo Christensen, Delia Garcés, Narciso Ibáñez Menta, Ángel Magaña y Enrique Muiño. La tensión entre una lógica comercial, que recuperara los modelos exitosos de las cinematografías globales, y la búsqueda de una representación ligada a lo local o lo regional, fue un componente central a lo largo de las quince películas que produjo la empresa: El gran amor de Bécquer (Alberto de Zavalía, 1946), Corazón (Carlos Borcosque, 1947), El hombre que amé (de Zavalía, 1947), El misterio del cuarto amarillo (Julio Saraceni, 1947), Corrientes, calle de ensueños (Román Viñoly Barreto, 1949), Hombres a precio (Bernardo Spoliansky, 1950), Lejos del cielo (Catrano Catrani, 1950), El alma de los niños (Borcosque, 1950), Rescate de sangre (Francisco 
Mugica, 1951), La pícara cenicienta (Mugica, 1951), Un ángel sin pudor (Carlos Hugo Christensen, 1953), El cartero (Homero Cárpena, 1954), El último cowboy (Juan Sires, 1954), El mal amor (Luis Mottura, 1955) y Surcos en el mar (Kurt Land, 1956).

Dentro de una historiografía del cine argentino que ha sido pensada, generalmente, desde y sobre la ciudad de Buenos Aires, Film Andes supone así una anomalía. Mientras que las características de su desarrollo permiten pensarla dentro del marco del cine clásico-industrial de esos años, su ubicación geográfica y simbólica por fuera de los límites de la capital argentina supone su pertenencia a espacios periféricos. En este sentido, la incorporación de una óptica regionalista parecería una alternativa para abordar su estudio. Desde esta perspectiva, Film Andes debería ser considerado por lo tanto desde una lógica regional que lo emparente, a su vez, con otros proyectos similares que surgieron en puntos diversos del país entre comienzos de la década de 1930 y finales de la de 1950. Ello incluyó desde iniciativas singulares, como Canción de la nieve (Guzzi Lantschner, 1954) en Bariloche o Mansedumbre (Pedro R. Bravo, 1952) en Tucumán, a otras con mayor alcance y aspiraciones, como las películas que filmó Ignacio Tankel en Chivilcoy con el sello de Oeste Film. Sin embargo, la envergadura del proyecto mendocino y las características de su producción exceden también estos marcos.

Film Andes constituye así una anomalía que tensiona los marcos conceptuales que han predominado en el estudio histórico del cine argentino. Este aspecto ha llevado a que su estudio, hasta el momento, haya sido limitado y su producción no sea considerada prácticamente dentro de los relatos que organizan el cine nacional. En su fundante historia, Domingo di Núbila (1959) relega cualquier comentario sobre la empresa a simples anécdotas que se resumen en algunas oraciones sueltas. En años más cercanos, el estudio de Fernando Martín Peña (2012) le dedica menos de una hoja destacando tres títulos y sin indagar en las particularidades de la empresa. En este marco, son pocos los trabajos que profundicen en la empresa y planteen ejes posibles de análisis para pensar su lugar dentro del cine nacional. Entre los más destacados se cuentan la mirada general, rica en testimonios, que realizó Maranghello (1999) y un estudio más cercano, centrado en la historia empresarial de la compañía, de Ozollo $(2004,2011)$. En ambos casos, sin embargo, no se ahonda en el carácter anómalo que marcó tanto su historia como su legado.

Esta dualidad constitutiva de Film Andes, entre una adscripción regional y un impulso industrial, puede pensarse como uno de los principales rasgos de la compañía y la irresolución de esta disputa como un eje fundamental para abordarla. Es el objetivo de este artículo proponer un recorrido sobre la historia de Film Andes, para analizar el modo en que esta disputa hacia su interior moldeó tanto sus prácticas empresariales como los modelos narrativos y representacionales de sus películas. A partir de la consideración de sus estrategias comerciales, sus transformaciones a lo largo de su existencia y su relación con los campos cinematográficos de la provincia, de la Nación y del continente, se ahondará en el complejo panorama que presenta la empresa y las tensiones que genera al momento de abordarla en el marco de las tradiciones historiográficas del cine argentino. 


\section{El cine de provincias en el período clásico}

En los últimos años la historiografía del cine ha vivido una renovación profunda, a partir del crecimiento cuantitativo de la investigación y la diversificación de miradas que fueron incorporando propuestas teóricas y metodológicas inexploradas. De este modo, la pregunta sobre el concepto de "cine nacional", que ha sido tradicionalmente uno de los interrogantes principales en torno a los que se han desarrollado los estudios históricos del medio fílmico a nivel global y especialmente en América Latina, ha tomado nuevamente un lugar central en los debates. El giro trasnacional, por ejemplo, supuso la irrupción de nuevas perspectivas que permitió contextualizar las dinámicas locales y establecer puentes y vínculos a partir de nociones como la circulación, el intercambio y las cooperaciones. De este modo, las especificidades y excepcionalidades atribuidas muchas veces a idiosincrasias locales han debido ser revisadas a la luz de este mapa más amplio.

Con un mecanismo inverso, la irrupción de miradas regionalistas hacia el interior de los países ha comenzado a generar un desequilibrio similar en torno a lo que se consideran "cines nacionales". Al establecer la coexistencia de experiencias diversas dentro de los límites territoriales, que en muchas ocasiones han sido relegadas dentro de los relatos que han configurado las historias nacionales, se ha puesto en tensión su pretendida homogeneidad. Lusnich (2018) sostiene que el revisionismo que se ha planteado en los últimos años, en torno a los cines regionales, se ha constituido alrededor a tres ejes centrales: la identificación de la región como una comunidad con una cultura común; las cambiantes relaciones región-Nación; y la articulación de vínculos interregionales hacia dentro de los países. En su gran mayoría, en el caso argentino, las propuestas vinculadas a los cines regionales han tomado como punto de partida la modernidad de los años '60 y la experiencia de la Escuela del Litoral como hito fundante. En cambio, estos estudios no han impactado aún en lo que respecta al período clásico. Si bien las historias generales del cine nacional, o del cine en las provincias, consideran en sus desarrollos las producciones realizadas durante esas décadas por fuera de Buenos Aires, éstas suelen estar relegadas a espacios secundarios desconectados de los grandes relatos organizadores.

Para poder ahondar en la dimensión regional de los cines de la primera mitad del siglo XX resulta pertinente considerar estudios que se han desarrollado en otros países latinoamericanos. En este sentido, los aportes de Corrêa de Araújo (2013) permiten incorporar algunas nociones que podemos recuperar para ahondar en el estudio de la experiencia de Film Andes. Retomando la propuesta de Autran (2010) sobre la necesidad de reconsiderar los "ciclos regionales" que caracterizaron al cine brasilero de las primeras décadas, Araújo ahonda acerca de esta modalidad que fue común a diversos países de América Latina como Chile o México, en los cuales antes de la irrupción del sonoro y la conformación de modelos industriales se plantearon posibles polos de producción cinematográfica a lo largo del territorio. En este sentido, señala la importancia fundamental que implicaba la posibilidad de acceso a la tecnología necesaria para encarar un proceso de producción y la estrecha vinculación con el campo 
exhibidor, que luego garantizaría un espacio para presentar las producciones. En esos períodos, como estrategia para compartir espacios dominados generalmente por cines extranjeros, estas producciones incluían noticieros y otros registros de la vida cotidiana para apelar a la identificación.

La propuesta de Araújo puede ser pensada en relación con las experiencias que estudió Martin L. Johnson, a las que denominó "films locales". A partir de una investigación sobre la producción fílmica desarrollada en Estados Unidos, por fuera de Hollywood en el período clásico, el autor clasifica esta heterogénea factoría como un modo más que como un género, "una constelación de diferentes tecnologías y redes que se expresaron en formas únicas históricamente específicas" (2018, p. 115). Dentro de ellas, Johnson destaca la existencia de films de promoción de las ciudades, versiones locales de géneros fílmicos industriales, noticiarios y docudramas para consumo interno. Si siguiéramos esta lógica, podríamos pensar en los múltiples polos que existieron en Argentina hasta mediados de la década de 1930, en los que se encararon producciones de pequeña escala que responden a las propuestas de Johnson. Las filmaciones de Domingo Mauricio Filippini en La Pampa, los diversos noticiarios producidos localmente en numerosas ciudades del país o los largometrajes de ficción de Camilo Zaccaría Soprani en Rosario, dan cuenta de un aún inexplorado panorama que, sin alcanzar la dimensión de los ciclos regionales brasileros, plantea una cartografía de producción fílmica argentina multipolarizada.

Dentro de este mapa cinematográfico nacional Mendoza misma contaba ya con antecedentes, antes de embarcarse en la aventura de Film Andes. Un primer referente del que se tiene noticia se encuentra en Alma de bohemio (1927), filmada por José Donna con una cámara de $35 \mathrm{~mm}$, que contó en su elenco con la participación de Mario Soffici y de la que se tiene constancia que fue proyectada en el Cine-Bar La Bolsa de la capital provincial (Alfonso, 2020). Ello se entroncaba en lo que Ozollo (2011) ha descripto como una prolífera cultura cinéfila en la provincia, que iba acompañada de un surgimiento constante de espacios de proyección y actividades vinculadas a lo cinematográfico. En este marco, ya a finales de la década de 1930 existió en la provincia una compañía productora local en el sentido que propone Johnson. En la localidad de General Alvear, en 1938, se creó Cinematografía Payén, un emprendimiento de un conjunto de jóvenes locales nucleados en la Biblioteca "Domingo Faustino Sarmiento" de aquella ciudad. En los dos años siguientes, bajo ese sello, se filmaron dos largometrajes de ficción - $L a$ chacra de Don Bautista (1938) y El poroto trágico (1940)—, un documental local General Alvear y su progreso (1939) - y numerosos cortos nucleados bajo el título de Noticiero Alvearense ${ }^{1}$. La producción de Payén, que contaba con la participación activa de los vecinos de la ciudad y cuya circulación se encontraba limitada a cines locales y poblaciones vecinas, plantea la inserción de la historia mendocina en este conjunto de pequeños polos de producción fílmica que existieron en Argentina en la transición hacia la consolidación del modelo industrial. ${ }^{2}$

1 Un mayor desarrollo sobre la historia de Payén puede encontrarse en la reseña escrita por Bugarin (2009).

2 Payén no fue, sin embargo, el único caso de este tipo de producciones en Mendoza. Con un espíritu 
Figura 1. Fotograma de La chacra de Don Bautista (Atilio Piacenza, 1938)

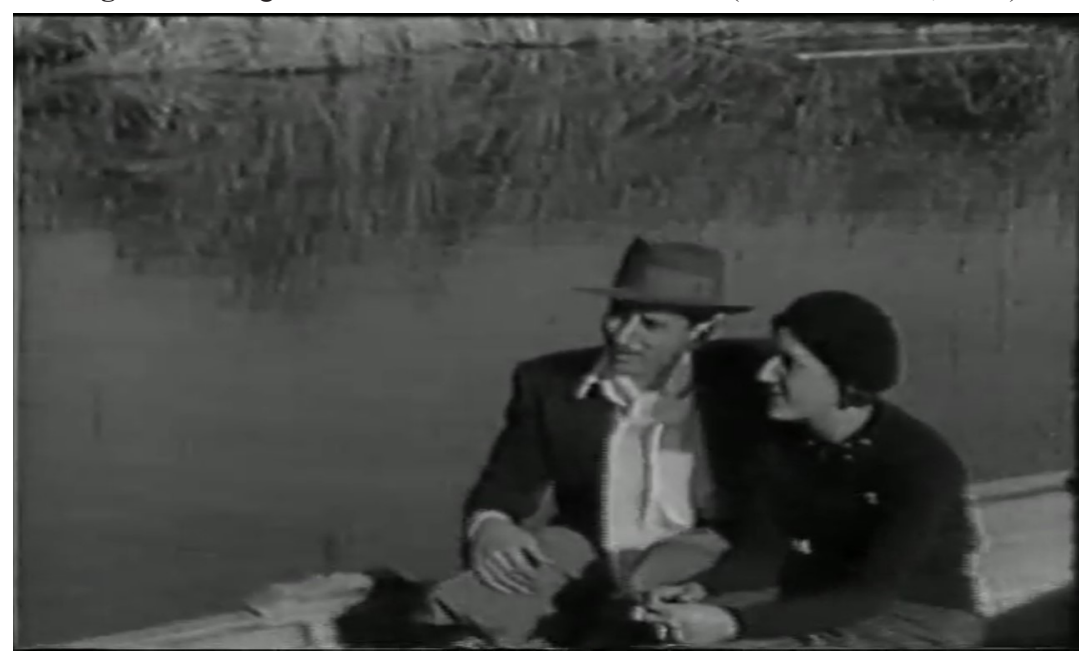

Este panorama permite dar cuenta de los modelos dominantes, dentro de lo que se puede pensar como cines regionales, en la primera mitad del siglo XX. Sin embargo, resulta pertinente retomar las observaciones de Flores (2019), quien, a partir de los conceptos de Marcelo Marchionni, señala que "podemos tener la imprecisión de considerar cine regional a cualquier tipo de fenómeno que esté circunscripto a determinado espacio, considerando regionales tanto a los films que se producen en una provincia o conjunto de provincias como a los que se realizan específicamente en un pueblo o ciudad, más asociado a una idea de cine local" (p. 288). Al pensar en los cines regionales en el período clásico, lo regional y lo local suele ser tratado del mismo modo, y es así que experiencias como la de Payén y la de Film Andes quedan incluidas en un mismo grupo, bajo un criterio estrictamente geográfico.

Sin embargo, el surgimiento de Film Andes a mediados de la década de 1940 trajo aparejada una visión diferente sobre lo que se podía esperar de la producción cinematográfica en una provincia y requiere, por lo tanto, pensar su problemática a partir de marcos que excedan la idea del film local. A partir de la incorporación de una impronta industrial, que buscaba ya desde un comienzo diferenciarse de experiencias como las de Payén para insertarse plenamente en el campo cinematográfico nacional, la empresa propuso un espacio de divergencia y un recorrido sinuoso en que la tensión industrial-regional fue constante. De este modo, abordaremos a continuación la historia de Film Andes para revisar la pertinencia del abordaje regionalista y exponer las divergencias que presentó la empresa frente a estos antecedentes, aspectos que permiten considerarla como una experiencia anómala dentro del cine producido en provincias en la Argentina.

similar, en 1947, se filmó en la localidad de Palmira El rapto de la Clarabella, un cortometraje dirigido por Vicente Rulo Lo Castro, quien lo produjo con su propia compañía, Rulofilm. Ozollo (2011) destaca asimismo la existencia de otras producciones como un cortometraje turístico patrocinado por la Junta Reguladora de Vinos en 1943 y cortos de la Fiesta de la Vendimia filmados por Argentina Radio Films. 


\section{Film Andes: una empresa cinematográfica}

Según reconstruye Ozollo (2004), el 19 de agosto de 1944 se realizó en Mendoza una asamblea a fin de constituir una empresa productora de películas de largo metraje a la que asistieron fundamentalmente empresarios vinculados a la burguesía vitivinícola, sector que había ido cobrando peso y dimensión en la región cuyana en las décadas previas. Junto a los bodegueros, se sumaron a la conducción de la empresa otros actores vinculados al campo intelectual y al político. Esta asamblea llevó a que el 23 de septiembre de ese año se constituyera oficialmente Film Andes, presidida inicialmente por el Dr. Lorenzo Soler y posteriormente, a partir de finales de 1945, por Arturo Santoni. Ozollo destaca que la presencia, al mando de la empresa, de este conjunto de hombres provenientes de la industria del vino marcó desde un comienzo el carácter industrial con que se encaró el emprendimiento. Resulta paradójico, en ese sentido, que este impulso se diera justamente en un momento en que la industria fílmica argentina atravesaba una profunda crisis a partir del contexto bélico internacional que había llevado a la escasez de película virgen, la imposibilidad de renovar los equipamientos técnicos y la pérdida de mercados internacionales. Al mismo tiempo, quizás haya sido justamente este panorama incierto y proclive a la renovación, junto con el crecimiento del apoyo estatal al sector cinematográfico a partir de medidas como la obligatoriedad de exhibición de la producción nacional, el que haya atraído a la dirigencia mendocina a ingresar en el mundo del cine.

Los empresarios comprendieron así que, para superar las barreras de lo local, debían encarar la producción fílmica combinando un conjunto de elementos fundamentales para una impronta industrial: la búsqueda de fuentes de financiación, el desarrollo de herramientas de producción propias, la conformación de redes de distribución y exhibición y la apelación a figuras y temáticas que resultaran atractivas más allá de las fronteras provinciales. Para ello, requerían contar con agentes que ya estuvieran participando del quehacer cinematográfico, para lo cual se contactaron con Juan José Barcia, que había fundado junto con el director Alberto de Zavalía la compañía Productores y Artistas de América (PYADA), con la cual se firmó un acuerdo para la distribución de las primeras películas producidas en Film Andes. Si bien PYADA garantizaba la posibilidad de insertar la producción en el mercado nacional, los directivos de Film Andes decidieron, al mismo tiempo, que los estrenos de las películas fueran en terreno mendocino. Para ello se llegó a un acuerdo de exclusividad de estrenos con los propietarios de la sala Cóndor. Este cine había sido inaugurado el 15 de junio de 1946 con la presencia del gobernador Faustino Picallo, numerosos miembros de su gabinete, el intendente de la capital provincial, la reina de la Vendimia de 1946 y una comitiva de productores y empresarios cinematográficos llegados de Buenos Aires. La sala fue un proyecto de gran envergadura que contó con la participación del arquitecto belga Alberto Bourdon, quien había sido responsable de la construcción del Cine Ópera en Buenos Aires. Para el establecimiento mendocino se retomaron varios aspectos, ya presentes en la sala porteña, como la decoración de los muros laterales con una escenografía que simulaba ser una aldea y un cielo estrellado en el techo que se iluminaba antes de 
cada función (Moretti, 2015) ${ }^{3}$. De este modo, Film Andes se aseguró la posibilidad de reproducir en su territorio de origen una dinámica de espectacularidad alrededor de la exhibición, similar a los estrenos que se realizaban en Buenos Aires.

El acuerdo con el cine Cóndor fue firmado cuando ya se encontraba en producción la primera película de la compañía, El gran amor de Bécquer, dirigida por Alberto de Zavalía. A falta de estudios de filmación propios, se alquilaron los sets Lumiton en Munro, dentro del área metropolitana de la ciudad de Buenos Aires. Al mismo tiempo, PYADA actuó aquí no sólo como distribuidora sino como coproductora, lo cual haría en las siguientes tres películas producidas por Film Andes: Corazón, El hombre que amé y El misterio del cuarto amarillo ${ }^{4}$. En este primer conjunto de películas de Film Andes es donde se hace más evidente la búsqueda de insertarse en la conversación cinematográfica nacional, mientras que el aporte mendocino se reducía al financiamiento de la producción. En todos los casos se trató de adaptaciones de obras de la literatura europea, un modelo que estaba en boga en esos años, tanto en Argentina como en otras cinematografías latinoamericanas. Aquí cobró gran fuerza la impronta de Zavalía, quien era el director de producción de PYADA, y a quien Maranghello (1999) atribuye el tono sofisticado de estos títulos. De este modo, si bien permitieron a Film Andes insertarse en el mercado y conseguir fondos para el crecimiento de la compañía, no lograron destacarse demasiado con la crítica o con el público.

Luego de este primer conjunto de producciones, la compañía comenzó a alejarse de la impronta de PYADA en búsqueda de definir un perfil propio. Por un lado, pasaron a hacerse cargo de la distribución a partir de la creación de ADOCA (Andes Distribuidora Organización Cinematográfica Argentina) con la cual se logró establecer una red de comercialización hacia todo el continente latinoamericano ${ }^{5}$. Por otro lado, también se terminó el vínculo con PYADA, en términos de producción, y se estableció un nuevo contrato con la empresa Movyart, que favoreció relatos generalmente centrados en las

\footnotetext{
3 Moretti (2015) señala que el Cóndor formó parte de una sucesión de trabajos en los que participó el proyectista Pedro Ribes, integrando la empresa Ribes, Indiveri y Cía., dedicados a la construcción de salas de cine en Mendoza. Además de la sala pensada para los estrenos de Film Andes, fueron responsables del Rex, el Mendoza, el Gran Oeste, el Gran Capitán y el Fantasio en la capital provincial, el Plaza y el Sportman en Godoy Cruz, el Mayo en San Martín y el Gran Sur y el Andrés en San Rafael. Ellos incluyeron desde salas barriales a grandes edificios fastuosos y monumentales, replicando un heterogéneo panorama de exhibición presente en las grandes ciudades.

${ }^{4}$ La diversidad de empresas que participaron de este proyecto se hace evidente en el título que Anchou (2000) dedica al apartado de Film Andes en su artículo sobre la producción independiente previamente citado. Allí lo denomina Film Andes (1946-1956), PYADA (1946-1947), Movyart Sociedad Cinematográfica (1948-1951), Lautaro Films (1951), Cinematográfica Callao (1952), Río Pilcomayo (1955), Mar del Plata Films (1955) y ADOCA (1951-1959). Bajo este rótulo nuclea tanto a las empresas asociadas a Andes como a aquellas que utilizaron sus estudios o buscaron interactuar con sus aportes filmando en provincias, como Lautaro (Mendoza), Río Pilcomayo (La Rioja) o Mar del Plata. Señala, en este sentido, que nunca han quedado del todo claros los términos reales de las asociaciones entre las empresas, variando entre productoras, distribuidoras y apoyos institucionales, algo que se hace evidente asimismo en los créditos de los films.

5 ADOCA eventualmente también distribuyó cintas chilenas como El ídolo (Pierre Chenal, 1952), mientras que al mismo tiempo se hizo cargo de la distribución regional de películas menores porteñas (Ozollo, 2004).
} 
vivencias de trabajadores en entornos hostiles (Anchou, 2000). Esta empresa tenía un perfil más vinculado a una lógica popular no cosmopolita, con una propensión a filmar en las provincias. En esos años produjo la película Patrulla Norte (Enio Echenique, 1951) que fue filmada en Formosa y también se encargó de distribuir realizaciones como Alma liberada (Edmundo del Solar, 1951), filmada en Mendoza por Lautaro Films, y Canción de la nieve, realizada en Bariloche.

Film Andes pasó así a producir películas de menor presupuesto, dirigiendo sus fondos a la construcción de estudios propios de filmación, que era una de las prioridades de la empresa. Por lo tanto, las siguientes realizaciones dejaron de lado la sofisticación europea para centrarse en relatos ambientados en territorio argentino. Al mismo tiempo, comenzaron a tematizar la relación de las provincias con la ciudad de Buenos Aires, a partir de historias de personajes migrantes internos. Bajo esta lógica, Estrellita y Corrientes, calle de ensueños —ambas filmadas por Román Viñoly Barreto-, suponen un conjunto interesante que, con menores pretensiones que los films anteriores, marcan el cambio de perfil de la compañía ${ }^{6}$. Las dos películas retomaron con ese fin modelos genéricos que ya estaban probados con éxito en el cine argentino, para darles aquí una impronta diferente al cruzarlos con el relato de la migración interna como eje central. Estrellita contaba así la historia de una ingenua pura e inocente que vive haciendo el bien a quienes la rodean, mientras que Corrientes... cuenta la historia de la búsqueda de estrellato de un conjunto de artistas y músicos. En ambos casos los films asumían la perspectiva de sus protagonistas, muchachas provincianas recién llegadas a la gran urbe porteña.

Ambas películas presentan la relación centro-periferia que se establece desde los pueblos del país con la ciudad de Buenos Aires, asumiendo justamente esta óptica externa del mundo de la ciudad. Una síntesis de esta mirada se presenta en los primeros minutos de Estrellita, donde imágenes de grandes edificios de la ciudad son acompañadas por una voz over que dice "Esto es Buenos Aires, una de las capitales del mundo. Acero y cemento bajo el cielo austral. Tres millones de habitantes, crisol de razas, puerta abierta a todos los hombres de buena voluntad. Sangre criolla forjó su poderío. Sueños de inmigrantes levantaron estos rascacielos. Buenos Aires es promesa de un mañana mejor." Aquí la imagen deja de mostrar grandes edificios y se desplaza a barrios humildes, mientras la voz sigue "Pero su espíritu no está solamente en su riqueza en sus rascacielos, en su poderío. Está en los miles de hogares que se levantan junto a la ciudad inmensa. Suburbios de Buenos Aires. En ellos brota la sangre que vivifica la ciudad. Esta es la historia de un hogar como hay muchos en la cintura de la gran Buenos Aires". 7

6 Como señala Anchou (2000), técnicamente Estrellita no es un film producido por Film Andes, sino por PYADA luego de que ambas empresas se separaran. Sin embargo, los equipos técnicos y creativos son en gran parte los mismos que los de Corrientes, calle de ensueños, por lo cual es posible pensarla dentro de un marco compartido.

7 En gran parte esta presentación se puede poner en relación con la introducción de Adolescencia (Francisco Mugica, 1942), uno de los principales referentes del cine burgués de ingenuas de comienzos de la década. Allí, se presentaba un hogar exaltando la armonía de la familia moderna, sin plantear su relación con el mundo exterior. Estrellita es en este sentido un film popular de ingenuas, que retoma sus elementos formales y los desplaza al sector de los migrantes internos del conurbano porteño. 
Figura 2. Yeya Duciel y Chas de Cruz en Corrientes, calle de ensueños (Román Viñoly Barreto, 1949)

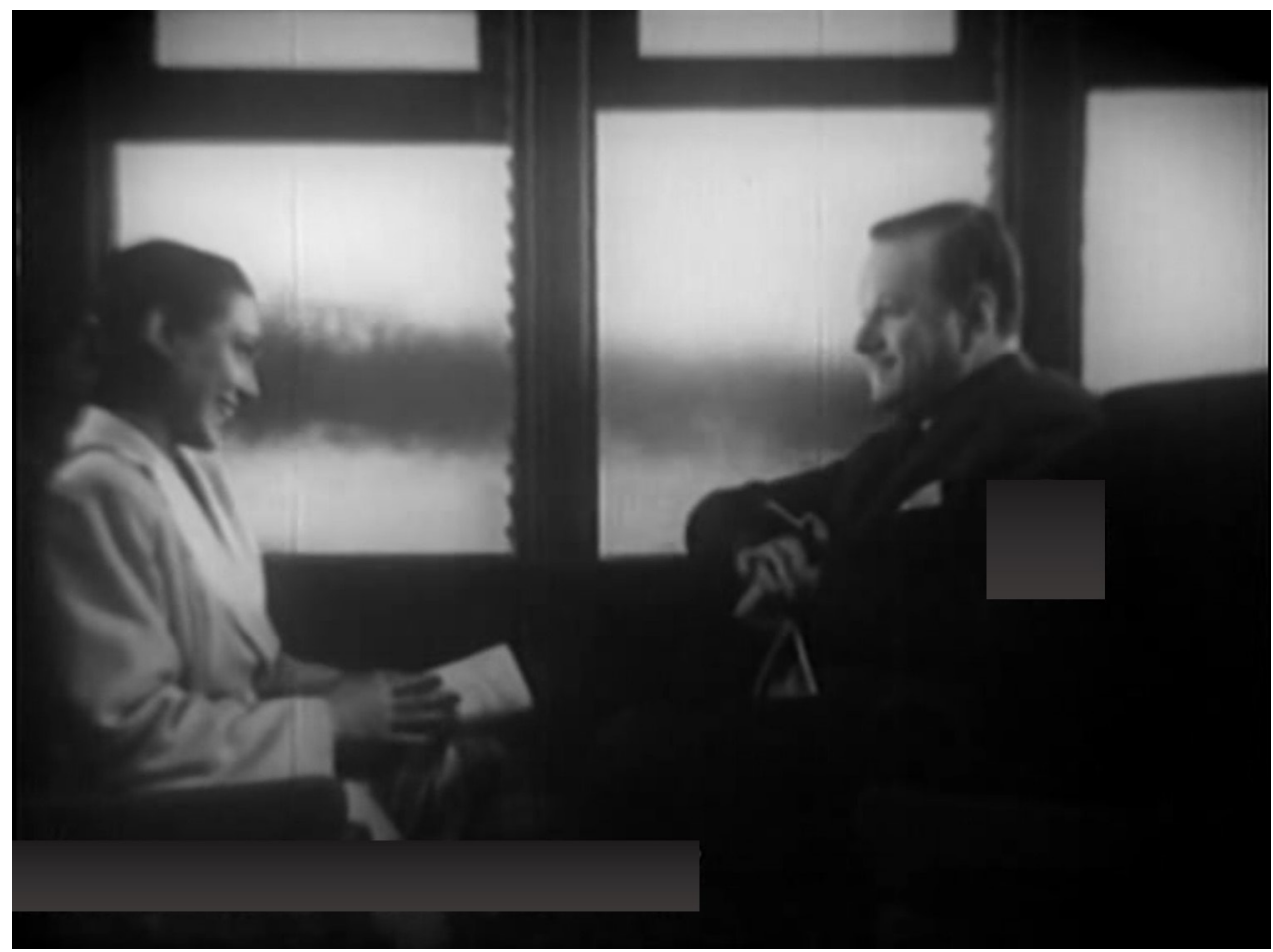

Así como Estrellita se ambienta en una humilde vivienda suburbana, Corrientes... lo hace en una pensión de artistas ubicada en pleno centro porteño. De este modo, ambas películas no solamente retoman los personajes migrantes, sino que se ubican claramente dentro de un universo popular. Este enfoque se hacía presente, asimismo, en el reemplazo de las grandes estrellas de los roles protagónicos-en pos del lugar destacado que cumplió en ellas la actriz Yeya Duciel, quien hasta ese momento solo había interpretado papeles secundarios en comedias burguesas. Lejos de las rubias glamorosas que poblaban las pantallas argentinas en esos años, Duciel presentaba una apariencia más humilde ligada a un imaginario popular. Al mismo tiempo, permitía un abaratamiento lógico de costos para la empresa que permitía asimismo incorporar nuevas modalidades y registros que condujeran prontamente a la producción totalmente local. Este posicionamiento de Film Andes se hace explícito en un fragmento del segundo film, donde el músico tanguero Enrique Delfino, interpretándose a sí mismo, mantiene una conversación con un joven músico en la que realiza una defensa de la música popular que puede leerse asimismo en sintonía con las aspiraciones de la compañía:

Delfino: Para que una música sea popular, todos tenemos que reconocer en ella algo nuestro, el dolor, la alegría, la esperanza. Una música triunfa, no cuando la ejecuta una gran orquesta sino cuando la silba un canillita o un organito la lleva por los barrios. 
Músico: ¿No sé cómo se puede conseguir eso?

Delfino: Sufriendo y viendo sufrir a los demás. Trabaje muchacho y acérquese lo más que pueda a la vida. Ella le enseñará ${ }^{8}$.

La enseñanza de Delfino se hacía presente en ambos films, donde se presentaban desenlaces en los que la alegría final implicaba sacrificios, pérdidas y desgracias. De este modo, Film Andes parecía anunciar el giro que iba a presentarse en los próximos meses con la inauguración de sus propios estudios de filmación, cuando comenzaría a presentar por primera vez frente al público nacional largometrajes producidos y rodados íntegramente en territorio mendocino.

\section{Film Andes: una empresa mendocina}

Corrientes, calle de ensueños fue filmada en los estudios de Argentina Sono Film, mientras que el film siguiente de la productora, Hombres a precio, de Bernardo Spoliansky, contó ya con gran cantidad de escenas filmadas en exteriores, aunque extrañamente fueron escenarios de la provincia de Jujuy. ${ }^{9}$ Ambas películas, estrenadas respectivamente en septiembre de 1949 y marzo de 1950, fueron las últimas producciones de la empresa que se filmaron antes de la inauguración de sus propios estudios de filmación en mayo de 1949. Localizadas en Godoy Cruz, las galerías eran presentadas como un símbolo de modernidad. Construidas en un edificio antisísmico, incluían departamento de maquillaje, edificio de sonido, galería de filmación, edificio de cámara transformadora y grupo electrógeno y edificio de talleres, mientras que en las afueras se construyó un lago artificial para poder realizar tomas en exteriores (Maranghello, 1999). De este modo, Film Andes abandonaba su condición de sello productor que dependía de alianzas y alquileres con otras compañías, para pasar a contar con cierta autonomía en sus proyectos y ser artífice de su destino.

Se debe destacar que esta mayor autonomía adquirida por la compañía se desarrollaba en un contexto de gran dinamismo de la industria, a partir de la decisión del gobierno nacional de establecer una primera línea de préstamos de fomento a productores cinematográficos proveniente del Banco de Crédito Industrial (Kriger, 2009). De este modo, al momento de insertarse en el circuito fílmico nacional con películas rodadas en sus propios estudios, el repertorio con las que debía competir en las carteleras había cambiado con una mayor presencia de cintas argentinas de diversa factoría, que duplicaba cuantitativamente el panorama nacional presentado en los años en los que se había conformado la empresa. En este contexto, según señala Ozollo (2011), la empresa

8 La presencia de Delfino se suma a la de numerosas figuras del espectáculo como Blackie, Francisco Canaro, Mariano Mores, Chas de Cruz, Domingo di Núbila, Tulio Demicheli y Carlos Borcosque que se interpretan a sí mismos en el film. Se puede pensar así en una muestra de apoyo y respaldo de este repertorio de figuras a la productora en un momento en que estaba por dar el gran salto que significaría la inauguración de sus propios estudios de filmación.

9 Hombres a precio presentaba también como eje central la dinámica entre Buenos Aires y ciudades del resto del país a partir de la historia de un periodista provinciano que pasa a trabajar en un medio de la Capital, donde se ve envuelto en una trama de corrupción política y empresarial. 
encaró también una reformulación con respecto a los mecanismos de financiamiento. Emprendió así una venta de acciones a ciudadanos mendocinos, buscando incorporar a comerciantes, profesionales y empresarios locales en el emprendimiento. De este modo, ya superada una primera etapa de acumulación de capital, se podría encarar una instancia de tornar más mendocina a la empresa. Sin embargo, si bien fue numerosa la participación de los co-provincianos, no alcanzó para poder afrontar producciones de mayor envergadura y los años siguientes vieron un desarrollo marcado por la incertidumbre.

Por un lado, continuaron vigentes algunos elementos que venían marcando las formas de trabajo de la empresa, como por ejemplo la presencia de realizadores que provenían del cine producido en Buenos Aires. La primera película filmada en los flamantes estudios, Lejos del cielo, fue dirigida por el italiano Catrano Catrani, quien venía de trabajar durante la década del cuarenta para los Estudios San Migue ${ }^{10}$. En los años siguientes se sumarían nombres destacados de la década anterior como Francisco Mugica y Carlos Hugo Christensen, mientras que Lucas Demare se incorporaría como director de producción. ${ }^{11}$ Por otro lado, si bien la mayoría de las películas que filmaría la compañía hasta mediados de la década resaltaban constantemente elementos de lo local, ello no significó que se dejaran de producir películas más ligadas a modelos genéricos de la industria cinematográfica global. En este sentido, films como La pícara cenicienta (Mugica) y Un ángel sin pudor (Christensen) se insertaban dentro de la lógica de las comedias burguesas filmadas en escenarios urbanos, con actores como George Rigaud, Ángel Magaña y Susana Freyre. De este modo, la empresa no parece haber buscado una identidad mendocina excluyente, sino una coexistencia entre distintas líneas temáticas y narrativas hacia su interior.

De todas formas, primó en esos años una mayor apelación a lo local a partir, fundamentalmente, de la conjunción de tres elementos: los escenarios, las figuras y las temáticas. Películas como Lejos del cielo, El alma de los niños, Rescate de sangre y El cartero tomaron estos ingredientes para dar visibilidad a diversos componentes de la vida y la cultura mendocina, a partir de relatos dramáticos protagonizados por personajes nobles. Mientras que las comedias burguesas citadas anteriormente fueron filmadas en escenarios interiores, este conjunto de películas - que apelaron a una presencia de lo local- tuvieron como uno de sus principales elementos la presencia constante de escenarios naturales. En este sentido, motivados en gran parte por la posibilidad de estar

\footnotetext{
${ }^{10}$ Catrani es una figura curiosa dentro de la historia del cine argentino y un nombre a tener en cuenta para considerar el cine industrial filmado en provincias durante las décadas de 1950 y 1960. En esos años filmó Codicia (1955), en Misiones; Al sur del paralelo 42 (1955), en Río Gallegos, Santa Cruz; Alto Paraná (1958), en Corrientes; Álamos talados (1960), en San Rafael, Mendoza; La fusilación o El último montonero (1963), en La Rioja; ;Santiago querido! (1965) en Tucumán y Santiago del Estero; y Tacuara y Chamorro, pichones de hombre (1967), en Coronda, Santa Fe. Sin que fueran necesariamente producciones provinciales, estos títulos dan cuenta de un particular interés del director por encarar producciones a lo largo del territorio argentino.

${ }^{11}$ Según señala Maranghello (1999), la presencia de estas figuras respondía a dinámicas que excedían lo cinematográfico, ya que Film Andes permitía al mismo tiempo una suerte de exilio interno durante el peronismo.
} 
filmando en medio de la cordillera, la representación de los espacios al aire libre apuntó tanto a un uso narrativo como a una espectacularización centrada en hacer visible su majestuosidad.

Figura 3. Fotogramas de Lejos del cielo (Catrano Catrani, 1950)

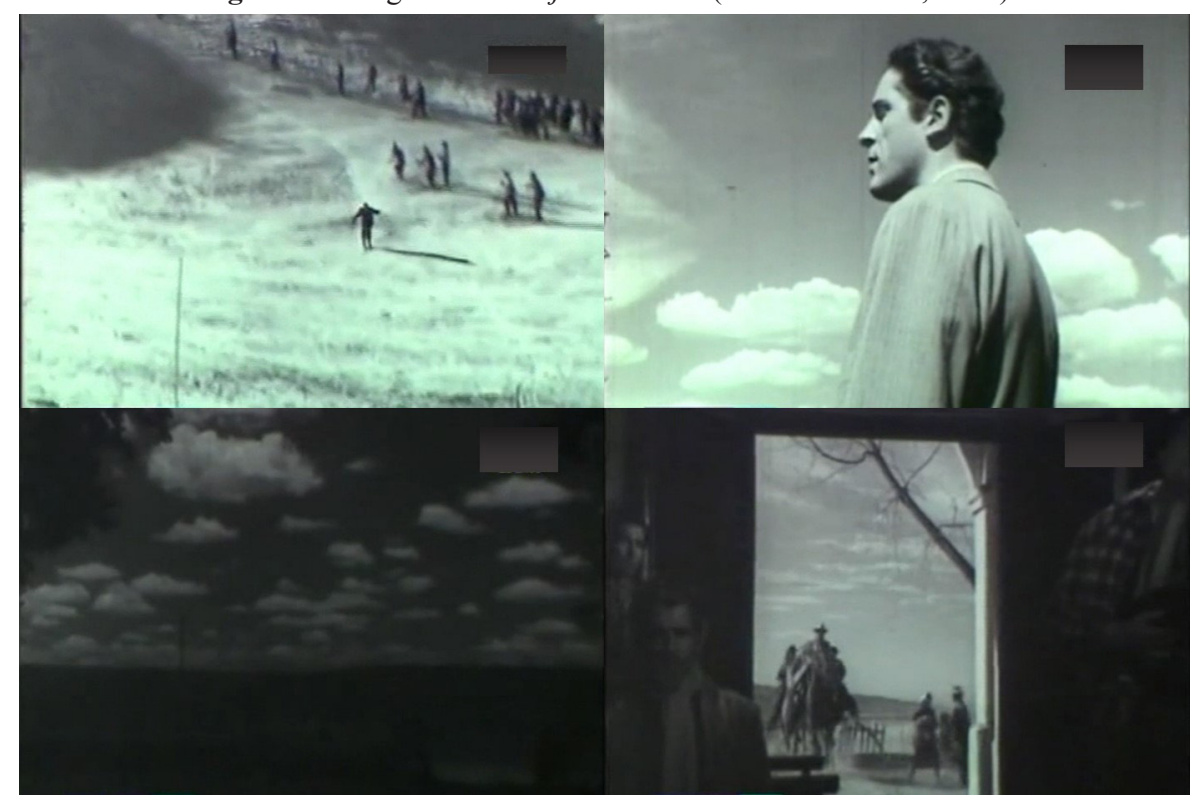

Es así que El cartero, por ejemplo, desde los títulos de inicio presentaba al protagonista andando en bicicleta para cumplir su oficio a través de pueblos, montañas y ríos. Mientras que aquí esos espacios eran parte de la caracterización del protagonista, en otras ocasiones su representación se asemejaba más a una idea de anuncio turístico. Lejos del cielo, por ejemplo, abundó en imágenes de la naturaleza filmadas con luz diáfana que resaltaba su bucolismo, al mismo tiempo que era recurrente la presencia de imágenes de esquiadores, incluyendo hasta un pequeño festival de luces. Estos escenarios, a su vez, fueron poblados por numerosos rostros que hasta ese momento no se habían hecho presentes en el medio cinematográfico nacional. Mientras que los papeles protagónicos de estos films eran interpretados por actores porteños como Tito Lusiardo o Jorge Salcedo, los repartos apelaban a la inclusión de figuras de la provincia. Según señala Maranghello (2019), la empresa abrió en 1949 un fichero de actores provinciales y comenzó a darles lugar fundamentalmente a figuras que provenían del mundo del radioteatro local como Mateo Martínez, Milka Durán, Servando Juárez y Tito Pagés. Asimismo, a través de la radio se convocaba a quienes quisieran participar en espacios menores o como extras, a través de lo cual se lograba un sentido de pertenencia y de relación con la comunidad provincial (2019, pp. 53-54). Es así que, por ejemplo, en la secuencia inicial de El cartero, Feliciano llegaba a entregar una carta a un hogar donde las mujeres escuchaban atentamente la locución radial. Luego de presentarlos a través 
de su voz, la película pasaba a presentar los estudios radiofónicos donde dos actores de radioteatro interpretaban una obra frente a un público emocionado. Si bien los títulos no lo aclaran, puede suponerse que eran figuras destacadas del medio local que podían de este modo cobrar mayor visibilidad.

La otra gran vía de presentación de valores locales era a través de las secuencias musicales con conjuntos en vivo. El cartero, por ejemplo, presentaba al conjunto de guitarras Aconcagua de Tito Francia. Asimismo, Rescate de sangre, ambientada en la época colonial, contaba con escenas de cuecas interpretadas por la orquesta sinfónica del Sindicato de músicos de Mendoza y el coro de la Universidad Nacional de Cuyo. De este modo, no era solamente el atractivo de los escenarios lo que ayudaba a configurar una imagen mendocina en los films, sino también la exposición de figuras propias frente al público nacional.

Todo confluía asimismo en una construcción simbólica que planteaban estas películas sobre Mendoza, en particular, y Cuyo, en general, que se hacía presente a través de los temas elegidos y el modo en que eran abordados dramáticamente. Mientras que $E l$ cartero y Lejos del cielo presentaban relatos melodramáticos sobre honestos personajes trabajadores, fueron otras dos películas donde se hizo más notoria la apelación a temáticas de orden local. El alma de los niños retomaba el reciente terremoto que había afectado a San Juan en 1944, para plantear un neorrealismo estilizado y sensiblero. Rescate de sangre, por su parte, narraba una gesta histórica ambientada en 1810 donde confluían la esclavitud, la gesta independentista y la construcción de las acequias. Ambas películas abordaban momentos de la historia local desde una óptica melodramática y solemne, que exaltaba lo local.

Es notorio que en todos estos films ocupaba un lugar central la referencia a la tierra, tanto en lo mostrado como en lo dicho, no sólo como lugar de pertenencia sino como símbolo de un conjunto de valores ligados al nacionalismo, al catolicismo y a un ideal tradicional de pueblo. Este aspecto era resaltado aún más a través de la idea de sacrificio, representado en la lucha por el agua y la construcción de las acequias que transformaban una tierra árida en un espacio para que creciera la civilización. Tanto Lejos del cielo como Rescate de sangre terminaban con montajes de torrentes vigorosos, que daban vida a la tierra mientras los protagonistas enunciaban mensajes a favor de la paz y la libertad. 
Figura 4. Fotogramas finales de Rescate de sangre (Francisco Mugica, 1951)

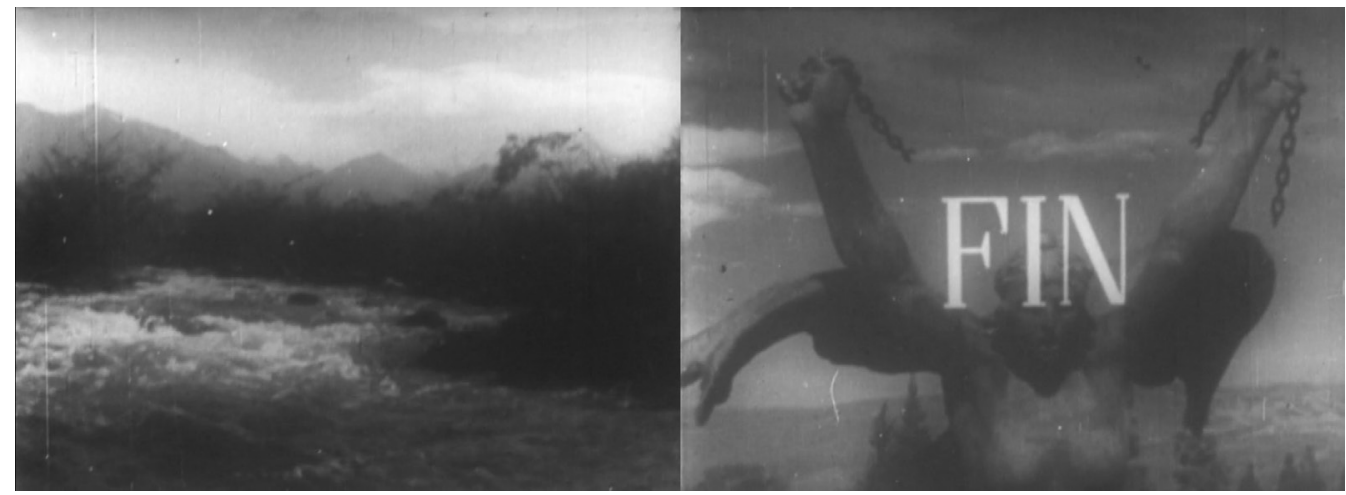

En este sentido, la producción de Film Andes rodada en sus propios estudios dejó de lado ese sentido complejo de lo popular que expresaba Enrique Delfino en Corrientes, calle de ensueños, para priorizar una visión bucólica de la pureza y bonhomía de la tierra mendocina. La dureza y crueldad de la vida urbana, que presentaban las películas de Viñoly Barreto, dejó lugar aquí a una visión maniquea y dicotómica donde el mal era traído por agentes extraños a Mendoza, mientras que los pobladores locales luchaban fraternalmente para ir creciendo de modo comunitario. Esta línea de producción no pudo, sin embargo, ser profundizada ni contar con mayor diversificación, ya que la empresa fue entrando en una crisis económica cada vez mayor. Resulta interesante en este sentido el testimonio de Enrique Walfisch, director de fotografía de larga trayectoria que en 1954 fue contratado para filmar las que serían las últimas dos producciones de Film Andes: El mal amor (1955) y Surcos en el mar (1956) ${ }^{12}$. Allí da cuenta de los problemas de costos y tiempos que suponía encarar una producción de tipo industrial a mil kilómetros de distancia del centro neurálgico del cine nacional:

El material eléctrico era en su totalidad importado de Estados Unidos, así como las cámaras y los equipos de sonido. Además, contaba con un grupo electrógeno de $75 \mathrm{kw}$ que permitía filmar en cualquier lugar con total independencia (...) Está bien que los bodegueros ganen mucha plata, pero ¿qué sentido tiene este estudio tan costoso, en una ciudad a $1100 \mathrm{~km}$ del centro artístico y cinematográfico del país?

Por empezar, había que llevar todo de Buenos Aires: artistas, directores, escenógrafos, maquilladores, etc., alojarlos en buenos hoteles y, lo más importante, el 'laboratorio' no existía. En Mendoza no había laboratorio, simplemente, porque no había producción para justificar su existencia. (2005, pp. 137-138)

${ }^{12}$ Ambas películas presentaban la conjunción de una presencia de imágenes provinciales, modelos narrativos genéricos vinculados al melodrama y la actuación estelar de grandes figuras del cine porteño. Tanto Mecha Ortiz en El mal amor como Enrique Muiño en Surcos en el mar marcaron así la persistencia de una dependencia de Buenos Aires que signó en parte a Film Andes hasta el final de su historia. 
La distancia geográfica se transformó así en otro factor que complicó las posibilidades de desarrollo de la empresa. La dependencia de Buenos Aires, tanto para las figuras y los técnicos como para los procesos de posproducción, aumentaba los costos y los tiempos y generaba una desventaja en la competencia comercial de Film Andes. Es así que junto con la venta de acciones se debieron encarar otras estrategias para poder financiar la producción.

Desde 1951, mientras producía sus propias películas, la compañía comenzó a alquilar sus estudios y sus equipos a otras producciones como Los troperos (Juan Sires, 1953), Acorralada (Julio C. Rossi, 1953), Marianela (Julio Porter, 1955), e incluso la segunda película argentina filmada en Ferraniacolor, Embrujo en Cerros Blancos (Rossi, $1955)^{13}$. En ellas Mendoza pasaba a ser fundamentalmente un territorio espectacular, sin ahondar en sus características o su impronta cultural, volviendo a tomar un lugar de espacio presentado desde la óptica porteña que sus películas estaban tratando de discutir. Esta dimensión fue así una instancia más de tensión entre las aspiraciones de un desarrollo industrial por parte de la compañía y la búsqueda de un perfil propio asociado a lo provincial que llevaba a sus producciones. Resulta lógico, en este sentido, que fuera justamente la crisis de la industria cinematográfica a nivel nacional, agudizada a mediados de la década de 1950, la que configuraría el marco para el cierre definitivo de Film Andes. En 1956 cerró sus estudios y con ello la experiencia de un cine con aspiraciones nacionales e internacionales producido en una provincia en un contexto de supremacía del modelo industrial ${ }^{14}$.

\section{Film Andes: una anomalía}

Tanto el desarrollo histórico de la empresa como las características de su producción dan cuenta de que Film Andes no fue tan solo una compañía productora más dentro del campo de la industria cinematográfica nacional, ni tampoco un simple emprendimiento regional que buscó dar espacio a la cultura local, sino que su particularidad radica en las dificultades que se presentaron al buscar congeniar ambas facetas. Las tensiones inherentes a la empresa, entre las aspiraciones industriales y las

\footnotetext{
13 "Una historia de película", Diario Los Andes, 27 de noviembre de 1989.

${ }^{14}$ Aunque Film Andes fue la única compañía que llegó a establecer un ritmo de producción constante, existieron otros emprendimientos similares en el período clásico en otras provincias. Quizás el que tomó mayor envergadura fue Córdoba Films, con el cual la provincia mediterránea buscaba replicar la experiencia mendocina asociándose inicialmente con la empresa Interamericana. La productora iba a debutar con la realización de Hacer la América o Nace un pueblo, a ser dirigida por Leo Fleider con la participación de Alberto Closas o Arturo García Buhr, basada en un argumento original de Alejandro Gutiérrez del Barro ("'Hacer la América' figura entre las primeras películas de 'Córdoba Film", Radiolandia $\mathrm{n}^{\circ} 1213,14$ de julio de 1951). Si bien este proyecto quedó trunco, en los años siguientes se estrenaron tres películas con este sello: Una ventana a la vida (Mario Soffici, 1953), en coproducción con Mapol; La delatora (Kurt Land, 1955) y En carne viva (Enrique Cahen Salaberry, 1955), ambas en coproducción con Guaranteed Films (Sorrentino, 2018). Por otro lado, Maranghello (2009), señala que en la propia región cuyana se crearon en esos años dos compañías productoras -Eos Film en Mendoza y la Primera Cooperativa de Trabajo Cinematográfico en San Luis-, aunque ninguna llegó a filmar.
} 
apelaciones a lo regional, suponen asimismo una problematización de la perspectiva teórica desde la cual abordar un fenómeno complejo como el de este emprendimiento.

Si retomamos la propuesta de Lusnich (2018), mencionada al inicio de este trabajo en referencia a los ejes que han guiado el estudio de los cines regionales, podemos considerar que la interregionalidad no aplica a las problemáticas surgidas en el desarrollo de la empresa, ya que, más allá de plantearse un acercamiento con Córdoba, la empresa no fomentó emprendimientos similares en otros puntos del país. El segundo eje, relativo a la relación con la Nación, resulta también insuficiente ya que, como sostiene Lusnich a partir de los conceptos de Carlos Aguirre Rojas, el ejercicio empresarial de Film Andes se basó en una multipolaridad constituida en torno a los conceptos de multiplicidad y diferencia. Argentina, metonimizada en el cine de Buenos Aires, suponía un proveedor de figuras y técnicos, pero no necesariamente una referencia al momento de encarar una producción que se planteó desde un primer momento basada en la heterogeneidad de géneros y estilos, propia del cine global.

El tercer eje propuesto por Lusnich, que postula la idea de la región como una comunidad con tradiciones propias, sí resulta pertinente para considerar las relaciones de Film Andes con la sociedad mendocina. No obstante, es aquí donde resulta fundamental ahondar en una dimensión que excede lo regional. Por un lado, es necesario entender gran parte del desarrollo de la empresa en el contexto de la industria cinematográfica durante el peronismo. Las adaptaciones de obras literarias europeas y las comedias burguesas fueron modelos genéricos que tuvieron una presencia destacada en esos años en el marco de una industria que buscaba, a través de ellas, presentar una faceta cosmopolita, moderna e internacionalista. De igual modo, la cambiante relación con lo popular, que alternaba entre una representación realista y una dominada por el maniqueísmo del melodrama, fue una dinámica constante en esos años.

Al mismo tiempo, no sólo el marco nacional sirve para dar mayor densidad a las particularidades de Film Andes, sino que, al ponerla en relación con otras empresas a nivel latinoamericano, resulta posible encontrar experiencias similares. En esos años, numerosos países de la región como Colombia, Perú y Venezuela encararon procesos de conformación de compañías cinematográficas nacionales donde se hizo presente la tensión entre la apelación a lo nacional y la conformación de modelos de producción industrial. Entre ellos, el caso de Chilefilms, cercano geográficamente a Mendoza, presenta gran cantidad de puntos de comparación a lo largo de su desarrollo. Como reconstruyen Peirano y Gobantes (2014), en Chile se creó en 1942 Chilefilms como parte de una iniciativa del Estado para conformar una empresa cinematográfica moderna y nacional. Para ello se llegó a un acuerdo de colaboración inicialmente con Argentina Sono Film y se contrataron técnicos y directores argentinos que participaron fundamentalmente de las primeras películas. Estas alternaron entre representaciones esquemáticas de la historia chilena y adaptaciones de obras de la literatura europea. La empresa se vio así envuelta en acusaciones de estar priorizando una imagen cosmopolita por sobre una representación de la chilenidad y siguió un derrotero incierto hasta finales de la década. 
Tanto la presencia de figuras externas, que influyeron en las temáticas y formas narrativas de las películas, como la impronta industrial buscada por los directivos y la ambivalencia por parte de las empresas con respecto a cómo encarar una producción comercialmente redituable - que también apelara a una idea identitaria - permite poner en contacto la experiencia de Film Andes con Chilefilms ${ }^{15}$. En ambos casos, el carácter relegado de su origen geográfico dentro del panorama general de la cinematografía nacional e internacional, respectivamente, se convirtió en un arma de doble filo. Por un lado, permitía una diferenciación en su propia inserción en el mercado distribuidor y exhibidor al adoptar una identidad como "cine chileno" o "cine mendocino", que podía servir como estrategia de comercialización. Al mismo tiempo, esta apelación restringía las posibilidades de las compañías, ya que si apelaban a modelos cosmopolitas serían acusadas de no tener color local y carecer de identidad, pero si se limitaban a la representación de las formas locales cercenaban la posibilidad de desarrollar una producción industrial diversa que apelara a distintos públicos.

Esta indeterminación fue planteada también por la historiografía posterior como motivo de las crisis y clausuras de ambas empresas. Mientras que en Chile ello se relacionó con el cosmopolitismo de los argentinos que atentaba contra el carácter popular que debía asumir el cine chileno (Peirano y Gobantes, 2014), en Mendoza algunas voces señalaban que, más allá de la crisis general de la industria cinematográfica nacional a mediados de los años cincuenta frente a la cual solamente sobrevivió Argentina Sono Film, los porteños habían jugado un rol negativo similar. Maranghello (2009) rescata, por ejemplo, las declaraciones de la periodista María Laura Palomba, quien años después afirmaba que "De haberse creído más en los talentos mendocinos y menos en la suficiencia porteña, tal vez hoy Film Andes estaría produciendo buen cine sobre las bases firmes de los valores locales"(p. 63).

De este modo, ampliar la mirada sobre Film Andes al pensarla en un marco nacional y continental, permite incorporar puntos de conexión que dan cuenta de su inserción dentro de un mapa fílmico general, en donde las tensiones entre las identidades locales y las necesidades comerciales ocupaban un rol central. Se debe destacar, sin embargo, que una de las últimas películas que produjo la compañía proponía una alternativa a esta dicotomía entre el cosmopolitismo y el localismo. El último cowboy, filmada por Juan Sires, presentaba una parodia sobre el cine del oeste, con un relato filmado en los Andes y ambientado en California. Como señala Araújo (2012) en su estudio sobre las producciones regionales durante el período silente, la impronta del cine de Hollywood era recurrente como un modelo de referencia, no necesariamente como simples imitaciones, sino también bajo estrategias de distanciamiento irónico, de homenaje o mediante procesos de hibridación con tradiciones locales ${ }^{16}$.

\footnotetext{
${ }^{15}$ Un caso particular que ilustra esta posibilidad de poner en relación a Film Andes con Chilefilms es el de Jack Hall, un, ingeniero óptico norteamericano que llegó en 1939 a Argentina acompañando a Carlos Borcosque. Hall partió a Chile a trabajar en Chilefilms a mediados de los años cuarenta y se quedó allí por dos años, hasta que los empresarios mendocinos fueron a buscarlo para ofrecerle hacerse cargo de la dirección técnica, el montaje de los estudios y la organización artística (Maranghello, 2009).

${ }^{16}$ Resulta interesante señalar en este sentido que El rapto de Clarabella, cortometraje citado anteriormente
} 
En este caso, esta referencialidad al cine de Hollywood se había visto acentuada por la presencia de compañías extranjeras filmando en Mendoza, entre las cuales había sobresalido el rodaje de El camino del gaucho (Way of a Gaucho, Jacques Tourneur, 1952), una producción de la Fox inspirada en episodios del Martín Fierro ${ }^{17}$. Retomando las vivencias de técnicos y otras figuras del cine mendocino en este rodaje, se encaró la producción de esta comedia protagonizada por Augusto Codecá, Héctor Calcaño y Héctor Quintanilla, actores de larga trayectoria en el cine cómico nacional.

Figura 5. Fotogramas de El último cowboy (Juan Sires, 1954)

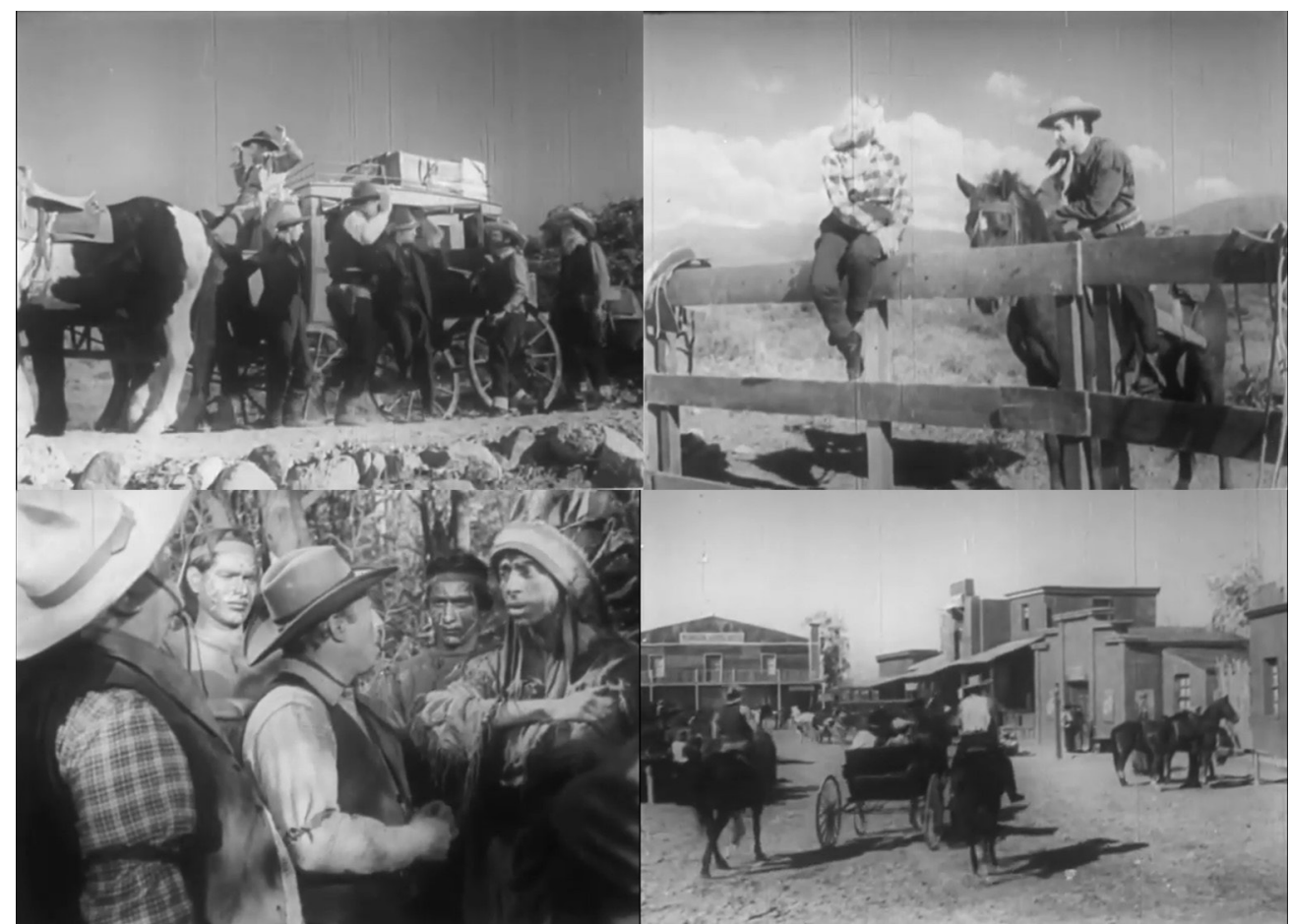

La película contó con una gran producción que incluyo escenas de ataques de indios, diligencias cruzando las montañas y la construcción de todo un pueblo del Oeste realizada por Giuliu Papini. Sin hacer referencias al criollismo o a la gauchesca, se planteó completamente como una parodia que deconstruía el cine del oeste, explicitaba

filmado de modo amateur en la localidad de Palmira en 1947, también tomaba el modelo del western para parodiarlo. Aquí se incluían escenas de aparente violencia y una protagonista interpretada por un hombre travestido. Según testimonios recogidos en el documental La Clarabella del Rulo (Matías Salgado, 2002) ello convirtió la experiencia en lúdica y divertida, al punto que uno de los entrevistados comenta que la inspiración para el film había sido el musical Escuela de sirenas, protagonizado por Esther Williams.

${ }^{17}$ El camino del gaucho es una película que presenta numerosos puntos de interés ya que fue producto de negociaciones de las empresas norteamericanas con Raúl Apold, a partir de la imposibilidad de enviar las ganancias de su filial local a los Estados Unidos. Un estudio detallado de ella se puede encontrar en el trabajo de Nicolás Suárez (2019). 
sus reglas y se burlaba de sus estereotipos. Desfilaban por ella personajes hablando en inglés, cowboys enanos, funebreros que lamentaban el avance de la civilización e incluso una escena en la que se cantaba en inglés El rancho 'e la Cambicha, canción folklórica popularizada unos años antes por Antonio Tormo. De este modo, la película presentaba un universo y una mirada novedosa, diferente, que retomaba escenarios cordilleranos, intérpretes mendocinos e incluso la experiencia provincial de los rodajes extranjeros en los años anteriores pero que pensaba al mismo tiempo en la posibilidad de atraer al gran público. Aquí no se dejaba de lado la presencia de lo regional, pero tampoco se reducía su presencia en la película a una función referencial de lo mendocino, sino que se lo integraba dentro de modelos genéricos y narrativos masivos. Sin tener tampoco que apelar al cosmopolitismo de las primeras películas de la productora, se planteaba la posibilidad de un film que integrara de modo novedoso las líneas divergentes que operaban hacia dentro de Film Andes.

Paradójicamente, El último cowboy fue el mayor éxito comercial de la compañía, al punto que Ozollo (2004, p. 133) propone que "es probable que, de haber producido algunas más de estas películas, hubiera sido otro el destino de la empresa". Sin embargo, la crisis imperante ya estaba avanzada y rápidamente dejó trunca la posibilidad de ahondar en esta línea y comprobar esta hipótesis ${ }^{18}$.

\section{Consideraciones finales}

La experiencia de Film Andes plantea la posibilidad de una perspectiva desplazada hacia lo que Tim Bergfelder (1999) denomina "interferencia", es decir aquellas experiencias alternativas que, dominadas por contradicciones y divergencias, alteran el orden general de los grandes relatos organizadores de la historia del cine. La tensión constante entre las intenciones industriales de la empresa de poder insertarse en el circuito comercial del cine nacional y la necesidad inherente de apelar a un ideal identitario — que respondiera a su origen mendocino- hicieron de este emprendimiento un objeto anómalo dentro del cine argentino que complejiza las miradas sobre lo nacional y lo regional.

La perspectiva dominante hasta el momento sobre este espacio de la cinematografía ha sido una que la ha relegado a los márgenes, donde ha primado una idea de experiencia trunca como se puede percibir en el subtítulo que le dio Maranghello

\footnotetext{
${ }^{18}$ El cierre de Film Andes no supuso necesariamente el fin inmediato de la producción cinematográfica en Mendoza. A comienzos de los años '60 se produjeron todavía algunas películas que utilizaron los estudios de Godoy Cruz antes de que estos fueran traspasados a una embotelladora de gaseosas. Álamos talados (Catrani, 1960), por ejemplo, recurrió a técnicas ligadas a la espectacularidad como la pantalla ancha del Argenscope y el Ferraniacolor para articularlo con un relato local basado en la obra de Antonio di Benedetto y escenas de la vendimia. La maestra enamorada (Saraceni, 1961), filmada también en pantalla ancha y color, presentaba a Lolita Torres en una de sus clásicas narrativas románticas, apelando a la exaltación del catolicismo, la escuela y la patria, al mismo tiempo que sus imágenes vendían los paisajes provinciales. El bruto (Rubén W. Cavallotti, 1962), por su parte, planteaba nuevamente una presencia destacada de los paisajes, pero con una puesta en escena moderna y con la actuación de quien sería uno de los principales aportes de Mendoza a la nueva etapa del cine nacional: Leonardo Favio.
} 
(2009) a su artículo sobre Film Andes: "Lo que no fue". De este modo, la imposibilidad de su desarrollo y las limitaciones de su producción han quedado como paradigmas de su lugar secundario, sin tenerse en cuenta que estas características fueron comunes a numerosas empresas cinematográficas nacionales e internacionales de esos años.

Como hemos desarrollado a lo largo del artículo, comprender a Film Andes en un contexto que dé cuenta de sus puntos de contacto con el quehacer fílmico contemporáneo permite iluminar las posibilidades y dificultades que implicaba la inserción en el mapa del cine argentino de una productora de origen provincial. En lugar de considerar a Film Andes como una excepción de la historia del cine, resulta más pertinente pensarla como una anomalía que se integra dentro de las dinámicas del medio fílmico nacional pero que al mismo tiempo presenta un desarrollo divergente.

Al día de hoy, el medio fílmico mendocino mantiene una relación ambigua con Film Andes. Mientras que el clúster que nuclea a los productores audiovisuales de la provincia lleva su mismo nombre, reconociendo su lugar como hito y marca de orgullo, otras miradas plantean una perspectiva diferente. El profesor y crítico Fausto J. Alfonso, por ejemplo, rechaza su pertenencia a una tradición local cuando plantea que Matar la tierra (Tito de Francisco, 1988) fue el primer estreno comercial producido en la provincia "desde aquellas producciones de Film Andes de los '50 (si éstas se considerasen íntegramente mendocinas, cosa que no)" (2020). De este modo, como señalamos previamente, la "mendocidad" de la empresa sigue siendo un punto de debate.

El legado de Film Andes, al mismo tiempo, marcó el posterior desarrollo de cualquier emprendimiento cinematográfico industrial por fuera de Buenos Aires. Si bien con los nuevos cines de la década de 1960 y los cineastas independientes de las décadas siguientes se vio un crecimiento de producciones en las provincias, no fue sino hasta el siglo XXI que se volvió a plantear la posibilidad de un emprendimiento afín. Curiosamente, fue también en la región de Cuyo que surgió San Luis Cine, que, con la principal diferencia de ser una iniciativa estatal, retomó la idea de poder producir un cine de gran escala por fuera del centralismo porteño. ${ }^{19}$

Film Andes supone así un fenómeno anómalo dentro de las directrices generales sobre las cuales se ha erigido el cine argentino, un actor periférico que buscó al mismo tiempo insertarse en las grandes ligas del cine nacional, sin por ello dejar de hacerse cargo de su pertenencia a una territorialidad relegada. Ahondar en sus características, en sus contactos con otras prácticas provinciales e internacionales contemporáneas, así como en las relaciones con experiencias afines anteriores y posteriores a lo largo del territorio, permite percibir la posibilidad de ir armando un entramado de anomalías e interferencias que proyecte una nueva luz sobre nuestro conocimiento del pasado y el presente del cine argentino.

\footnotetext{
${ }^{19}$ San Luis Cine replicó muchas de las características de Film Andes señaladas a lo largo de este artículo, desde un proyecto inicial planteado con una mirada integral del campo cinematográfico a una búsqueda de figuras del cine industrial, una indeterminación en las características temáticas y narrativas de su producción y una constante incertidumbre con respecto a sus perspectivas de desarrollo.
} 


\section{Referencias bibliográficas}

Alfonso, F. J. (2020). "El cine mendocino en 20 momentos (Nota 1)". El pacto de Fausto. Recuperado de: https://el-pacto-de-fausto.webnode.com.ar/news/el-cinemendocino-en-20-momentos

Anchou, G. (2000). "Veinticinco años de producción independiente. Las fronteras ignoradas". En C. España (dir.), Cine argentino: industria y clasicismo, Tomo I, (pp.464-583). Buenos Aires: Fondo Nacional de las Artes.

Araújo, L. C. de (2013). "A produção regional brasileira: relações com experiências latino-americanas e com o modelo norte-americano”. En S. Dennison (org.), World cinema: as novas cartografias do cinema mundial, (pp.89-99). Campinas: Papirus.

Autran, A. (2010). "A noção de "ciclo regional" na historiografía do cinema brasileiro". Alceu 10(20), enero-junio, 116-125. Recuperado de: http://revistaalceu-acervo.com.puc-rio.br/cgi/cgilua.exe/sys/start. htm? from $\% 5$ Finfo $\% 5$ Findex $=9 \&$ infoid $=374 \&$ sid $=32$

Bergfelder, T. (1999). "Negotiating Exoticism: Hollywood, Film Europe and the Cultural Reception of Anna May Wong". En A. Higson \& R. Maltby (eds.), "Film Europe” and "Film America". Cinema, Commerce and Cultural Exchange, (pp.302-323). Exeter: University of Exeter Press.

Bugarin, R. (2009). "Reseña Biográfica - Actividad Cinematográfica". Amado Sad. Recuperado de: http://amadosad.blogspot.com/2009/03/resena-biografica-laborinstitucional-v.html

Di Núbila, D. (1959). Historia del cine argentino. Tomo II. Buenos Aires: Edición Cruz de Malta.

Flores, S. (2019). "La producción regional en el cine argentino y latinoamericano". Imagofagia, 20, 279-298. Recuperado de: http://www.asaeca.org/imagofagia/ index.php/imagofagia/article/view/1935

Johnson, M. L. (2018). Main Street Movies: The History of Local Film in the United States. Bloomington: Indiana University Press.

Kriger, C. (2009). Cine y peronismo: el Estado en escena. Buenos Aires: Siglo Veintiuno Editores.

Lusnich, A. L. (2018). “Constitución y características del campo cinematográfico de la región de Cuyo: un balance histórico”. AURA, Revista de Historia y Teoría del Arte, 8, 71-88. Recuperado de: http://www.ojs.arte.unicen.edu.ar/index.php/aura/ article/view/592

Maranghello, C. (1999). "Film Andes: Lo que no fue". La mirada cautiva, 3, 50-64.

Moretti, G. A. (2015). "Pedro Ribes, de 'dibujante -proyectista' a 'empresarioconstructor'. Mendoza (1932-1962)”. Registros, 12, 53-74. Recuperado de: https://revistasfaud.mdp.edu.ar/registros/article/view/41

Ozollo, J. (2004). "La California argentina. Film Andes y la industria vitivinícola mendocina (1944-1957)". Universum, 19(2), 126-137. Recuperado de: http:// dx.doi.org/10.4067/S0718-23762004000200008 
Ozollo, J. (2011). Informe sobre la actualidad y la historia de la cinematografía mendocina. Mendoza: Universidad Nacional de Cuyo.

Peirano, M. P. \& Gobantes, C. (eds.) (2014). Chilefilms, el Hollywood criollo. Aproximaciones al proyecto industrial cinematográfico chileno (1942-1949). Santiago de Chile: Editorial Cuarto Propio.

Peña, F. M. (2012). Cien años de cine argentino. Buenos Aires: Biblos.

Sorrentino, P. (2018). "Cine en Córdoba: el entramado detrás de un hito". AURA, Revista de Historia y Teoría del Arte, 8, 8-28. Recuperado de: http://www.ojs.arte.unicen. edu.ar/index.php/aura/article/view/590

Suárez, N. (2019). "Los gauchos angloparlantes y la pampa en Technicolor: versiones y perversiones del Martín Fierro en Way of a Gaucho (1952) de Jacques Tourneur". $452^{\circ} \mathrm{F}$ : Revista de Teoría de la Literatura y la Literatura Comparada, 20, $126-$ 148. Recuperado de: https://revistes.ub.edu/index.php/452f/article/view/22592

Wallfisch, E. (2005). 50 años detrás de una cámara: nostalgias del cine argentino. Buenos Aires: SICA Ediciones. 